CURRENT RESEARCH JOURNAL OF PHILOLOGICAL SCIENCES 2(12):

190-194, December 2021

DOI: https://doi.org/10.37547/philological-crjps-02-12-36

ISSN 2767-3758

(C)2021 Master Journals

Crossref do

81 Google

Accepted21 ${ }^{\text {th }}$ December, 2021 \& Published 26 th December, 2021

\title{
MODERN AND INTERACTIVE METHODS OF TEACHING LEGAL ENGLISH
}

\section{Sayfiyeva Komila Kamolidinovna}

English Teacher At Tashkent State Law University, Uzbekistan

\section{ABSTRACT}

Teaching legal English has become in demand in the opportunities for those professionals who know English due to globalization, strengthening of economic ties of Uzbekistan with foreign countries and the connection with the expansion of strengthening at a good level. English teachers should help to the development of skills that will help law students to become competitive. Teaching legal English is a complicated but interesting process. When deciding to teach this sublanguage, it should be borne in mind that there are several modern and interactive methods. Teaching legal English to students requires using them in lessons in order to be effective and efficient at the same time. Various activities of these methods are used by teachers with the aim of teaching in deeper perspective.

KEYWORDS: - Legal English, interactive methods, sublanguage, learning activity, legal systems.

\section{INTRODUCTION}

Teaching legal English is a process that requires an understanding of the following features outlined below. Firstly, it is advisable to start teaching legal English if the students' level of proficiency in general English, including grammar, is not lower than intermediate, i.e. when a student can competently construct a sentence and, in general, is able to adequately express his thoughts in English. Secondly, a fairly solid knowledge of law is needed, since the study of legal English is carried out in a comparative way, i.e. in the process of studying different legal systems are compared. Thirdly, English legal vocabulary is difficult even for native
English speakers themselves, not to mention nonnative English speakers, because it includes Latinisms, French and Anglo-Saxon words and phrases, professional jargon and formal expressions, cliches and thus presents sufficient complexity for people studying both English and common law. Often, students of legal English have to analyze not only a legal term, but also a whole layer of vocabulary (including English-English definitions) related to any area of law, correlate with those concepts and terms, which forces them to study a large amount of material on the topic and, of course, requires a lot of time. 
CURRENT RESEARCH JOURNAL OF PHILOLOGICAL SCIENCES 2(12):

190-194, December 2021

DOI: https://doi.org/10.37547/philological-crjps-02-12-36

ISSN 2767-3758

(C)2021 Master Journals

Crossref doi

gil Google

Accepted21 $1^{\text {th }}$ December, 2021 \& Published 26 $6^{\text {th }}$ December, 2021

General language training should be combined with professionally oriented training. In groups with a sufficiently high level of general language training, it is more effective to immediately begin special professionally-oriented training. Conversely, in groups with a low and average level of English proficiency, it is necessary to focus first on the general language training of students, and then on professionally oriented. Grammatical material should always be worked out and fixed in oral speech. It should be noted that the language level of preparation of applicants entering the faculty of law leaves much to be desired. However, despite this, the motivation of incoming students to learn English is usually high, since everyone knows that a career as a lawyer with knowledge of English gives great professional prospects. What are the features of teaching English to law students? For many years, the priority in teaching English has been given to grammar, vocabulary study, reading and literary translation. However, in recent years, the question of the practical use of a foreign language has arisen. When teaching English to students of law major, general language and professional language training should be carried out in a complex. The content of the training should involve reading authentic texts from the very beginning and using them as a means of teaching oral speech. Considering the problem of students studying in the specialty jurisprudence, I would like to note that it is extremely important for them to freely navigate in various educational and legal systems. It is also necessary to always remember about the legal system of the foreign countries. This is important because the legal institutions in them may differ significantly. For example, the terms "solicitor" and "barrister" exist only in British law, "counselor" (adviser, lawyer) - in the USA and Ireland. After all, the problems of socialization are always relevant when learning a foreign language. When teaching law students a foreign language, teachers should bear in mind that a modern specialist needs to have a level that would allow him to communicate, if necessary, with specialists from other countries. To do this, he must know the basics of grammar, but, most importantly, they must know the vocabulary of a legal orientation. After all, provided that a future lawyer has a grammatical minimum that covers the basic rules of morphology and syntax and allows you to correctly understand a foreign language text, but does not have a professional vocabulary, it is impossible to feel free in a conversational situation with other lawyers and not get lost when discussing any professional situation. Therefore, an important role in the foreign language training of law students is given to the assimilation of professional vocabulary. The assimilation of lexical units is carried out in order to develop oral speech skills and is aimed at the implementation of communication skills and an adequate response in typical situations of professional communication, both oral (to make messages concerning a professional topic) and written (the ability to make a resume, any legal papers, etc.). It should be clearly understood that legal documentation and communication have their own characteristics. Firstly, it is clarity and conciseness in the transmission of information. Information should be transmitted so that a person is sure that it is understood correctly. It is important to be able to operate with basic models, to understand logic, to master vocabulary that has certain features in jurisprudence. After all, in jurisprudence, wellknown words are often translated quite differently. As for the development of oral-speech skills, those that have a legal orientation should be selected from the topics of oral speech. Thus, the communicative competence of law students in English should be professionally oriented. Teaching English to law students implies the development of their necessary professional competence. Achieving this goal becomes possible thanks to special teaching methods that are aimed at mastering and 
CURRENT RESEARCH JOURNAL OF PHILOLOGICAL SCIENCES 2(12):

190-194, December 2021

DOI: https://doi.org/10.37547/philological-crjps-02-12-36

ISSN 2767-3758

(C)2021 Master Journals

\section{Crossref do) 81 Google}

Accepted21 ${ }^{\text {th }}$ December, 2021 \& Published $26^{\text {th }}$ December, 2021

working out new lexical and grammatical material. Professionally-oriented Case studies should be an integral part of most classes for teaching oral communication. The basic legal sciences, such as criminal law, international law, civil law and many others should be widely represented in the English language training program for law students, in order to form a basic country-specific training of a legal nature. Independent work of students, which expands the professional lexical and grammatical base of students, is of no small importance when learning English. The effectiveness of teaching English depends on the diversity and accessibility of the presentation of legal language material for students. Thus, it can be concluded that every law student who has completed an English course at the university should read and understand legal texts, as well as express his thoughts freely enough in English in the most typical situations of legal life with some additional training. Our world, our society and our consciousness are changing rapidly today. Changes taking place in all spheres lead to innovations in the education system. Today, teachers need to prepare students to work in changed conditions, take an unconventional approach to solving various situations, and organize their activities on a creative basis. The higher school faces new challenges, in particular, the successful integration of students into the educational process. To effectively solve their professional tasks, a lawyer must have the necessary knowledge and skills of a general theoretical and applied nature. Another cognitive way to immerse yourself in the legal culture in the process of learning English will be to study the sources of American and English law themselves. In the classroom with students, you can read some regulations of England and the USA at the discretion of the teacher, for example, the US Constitution in the original text, "Crimes. The Code of Laws of the USA", the legislation of England, "Law of Property act", the Law on Crime, etc.
Also, in teaching students, it is necessary to pay great attention to communication in English, which has a professional orientation. An important role in this case is played by interactive methods of teaching English, namely discussions, debates, educational role-playing games of a professional orientation. In the modern approach to teaching a foreign language, the basis of the educational process is not only the assimilation of knowledge and the study of the language system, but also and the development of creative and cognitive abilities of each student in a professional orientation. The most effective method is a game method, the essence of which is modeling certain situations as close as possible to real ones.

Cognitive goals should be supplemented with behavioral goals. The most effective and relevant in modern education is the technique of role-based communication, methods of stimulating speech activity and others. New business games with the use of a foreign language should be widely used in universities, carrying out such forms of work that a future specialist may need in further practical activities. Such gaming activities should be limited to thematic frameworks, communicative and professional tasks. The game also stimulates group cooperation, speech interaction aimed at solving educational tasks. Here it is important to determine the game situation, which should have a professional orientation; the game role that determines the game actions of the players (this may be a lawyer, judge, prosecutor, prosecutor, defendant, etc.). In this case, a large role is assigned to the teacher, which consists in designing a game situation, selecting educational material, setting goals and implementing tasks.

In particular, the teacher must carefully prepare the means for conducting game activities, which can serve as various schemes, drawings, maps, slides, technical training tools, etc. Students will be very 
CURRENT RESEARCH JOURNAL OF PHILOLOGICAL SCIENCES 2(12):

190-194, December 2021

DOI: https://doi.org/10.37547/philological-crjps-02-12-36

ISSN 2767-3758

(C)2021 Master Journals

Crossref doi

gil Google

Accepted21 ${ }^{\text {th }}$ December, 2021 \& Published $26^{\text {th }}$ December, 2021

interested in various speech games. For example, playing the role of a policeman, a victim and a suspect. This may include conducting an interrogation of a suspect, describing the appearance of a suspect, conducting a trial on a civil claim, etc. It is also possible to implement the development of grammatical material using legal vocabulary. For example, when training a modal verb, you can give out cards with legal vocabulary, such as:

- $\quad$ He must have been arrested, but I don't know for sure if he was arrested or not.

- He could have been searched, but not searched.

- $\quad$ No one is obliged to testify against himself, his close relatives, etc.

To implement the educational process in this direction, an English teacher must have competent knowledge of the future profession of law students. That is, a teacher teaching English to future lawyers should be guided by legal terminology, the legal culture of the native country and the countries of the language being studied, various legal phenomena. Having considered the legal culture of the native country and the countries of the studied language, the following areas of activity can be distinguished that make up the teaching of English to law students:

- $\quad$ The legislative sphere;

- $\quad$ Executive power;

- The Police;

- Civil law;

- $\quad$ Criminal law;

- $\quad$ The judicial system.

These spheres are interconnected and are included in the general concept of law. The teacher needs to acquaint students with the legal culture of the countries of the language being studied. After all, there are institutions in the system of English law that are not available in the legal system of other countries.
In my lessons we usually use the authentic reading and listening materials for legal English from these web sites: www.abajournal.com, www.lawyermonthly.com, www.lawyersweekly.com.au, thestudentlawyer.com, injury.findlaw.com, www.lawgazette.co.uk, www.law360.com, www.lawsource.com, dlj.law.duke.edu, www.ejls.eu, www.ejcl.org, harvardhrj.com, www.law.com, www.breakinglegalnews.com and others.

\section{Results AND DISCUSSIONS}

Without presenting the necessary background knowledge by the teacher, it is impossible to achieve full understanding of texts by students. As for the legal vocabulary, it has special properties, since it is specific. There are many words that in everyday English will mean one thing, and in legal English another. For example, the expression "to be charged with" in everyday English will mean "to assign certain tasks, to be responsible for something", and in the legal sphere will mean "to be charged for something", the word "allowance" in general English means "pocket money", in the legal sphere, it means "benefit" or "sentence" means "sentence", in jurisprudence, "sentence", "just" just, just, just, etc., in legal specifics, "justice", etc.

\section{Conclusion}

In conclusion, I would like to note that the effectiveness of professionally oriented legal English language teaching depends not only on the students, but also on the work of the teacher himself, who must have competent knowledge, be able to organize the educational process in such a way that students in the classroom can easily and with interest assimilate educational material.

Thus, upon graduation, students should not only understand legal texts and terms, but also freely express their thoughts, communicate and also use 
CURRENT RESEARCH JOURNAL OF PHILOLOGICAL SCIENCES 2(12):

190-194, December 2021

DOI: https://doi.org/10.37547/philological-crjps-02-12-36

ISSN 2767-3758

(C)2021 Master Journals

crossref do) :810 Google

Accepted21 ${ }^{\text {th }}$ December, 2021 \& Published $26^{\text {th }}$ December, 2021

English in their further professional activities.

\section{REFERENCES}

1. Amy Krois-Lindner \& Matt Firth "International Legal English: A Course for Classroom or SelfStudy Use: Student's Book". "Cambridge University Press". 2008

2. Anderson Anne \& Tony Lynch. "Listening". Oxford University Press. 1988

3. Claire Elizabeth. "ESL teachers' activities kit". Prentice Hall Direct. New Jersey. 1998

4. Gillian D. Brown, Sally Rice "Professional English in Use - Law", Cambridge University Press, 2007

5. Hadfield Jill. "Advanced Communication Games" Longman Press. New York. 1997

6. Hess Natalie. "Teaching Large Multilevel Classes" Cambridge University Press. Cambridge. 2005

7. Law Barbara. "Assessment and ESL": An Alternative Approach Teachers Guide Edition. Portage \& Main Press. London. 2007

8. Murtha Sheila \& Jane Airey O'Connor. "English the American Way: A Fun ESL Guide to Language \& Culture in the U.S”. Research \& Education Association. Washington. 2011

9. Schubert F - "Introduction to law and legal system". Wadsworth, Boston, 2008

10. Ur Penny. "Teaching Listening Comprehension", Cambridge. 1984

11. Vernon Shelly Ann. "ESL Classroom Activities for Teens and Adults: ESL games, fluency activities and grammar drills for EFL and ESL students". Create Space Independent Publishing Platform. 2012

12. Wyatt R. "Check your English Vocabulary for Law". Third Edition. A \& C Black, London, 2006 